\title{
1985. aasta nõukogude alkoholipoliitika ja selle tagajärjed Eesti NSVs
}

\author{
Kelli Arusaar-Tamming
}

\begin{abstract}
Teesid: Nõukogude Liidus 1980. aastate keskpaigas alanud alkoholipoliitika karmistamine põhjustab avalikkuses tänaseni vastukajasid, enamasti peetakse toonast karskuskampaaniat tulutuks. Toonase alkoholipoliitika teostust ja tagajärgi Eesti NSVs pole ajaloolased käsitlenud kuigi põhjalikult, süvitsi minevamaid uurimusi on ilmunud eelkõige meedikute sulest. Aastatel 1985-1987 teostatud alkoholipoliitika karmistamine ei seisnenud vaid joovastavate jookide kättesaadavuse piiramises, tähelepanu pöörati ka karskete eluviiside propageerimisele ja teavitustööle. Mööda ei vaadatud ka juba alkoholist sõltuvusse sattunutest. Analüüsides 1980. aastate alkoholitarbimist legaalse alkoholi müügi aruannete põhjal, ilmneb alkoholi tarbimise märgatav vähenemine aastatel 1985 ja 1986. Kuivõrd ainuüksi müügistatistikale tuginedes jääks märkamata võimalik illegaalse alkoholi osa kasv, on käesolevas töös alkoholi tarbimise hindamiseks kasutatud ka kaudseid näitajaid: fataalsete alkoholimürgistuste ja alkoholipsühhooside esinemise sagedust. Viimaste kõrvutamisel legaalse alkoholi müüginumbritega ilmneb trendide kokkulangemine.
\end{abstract}

Märksõnad: alkoholipoliitika, alkoholitarbimine, rahvatervis, sotsiaalpoliitika, vigastussuremus

\section{Sissejuhatus}

Kuigi Mihhail Gorbatšovi alkoholipoliitika põhjustab avalikkuses veel tänagi rohkelt arutelusid, on teema Eesti ajalookirjanduses leidnud vaid põgusat vaatlemist üldkäsitluste raames, ilmunud pole ühtki antud teemat eraldi käsitlevat uurimust. 1980. aastate keskpaiga alkoholipoliitikat Eestis, eelkõige selle mõju alkoholitarbimisele ja rahvatervisele, on uurinud psühhiaatrid ja narkoloogid. Põhjalikumalt on teemaga tegelnud Anti Liiv (Liiv 1990a; 1990b; 1991a; 1991b; 2000). 2000. aastal ilmunud artiklis "Sõltuvushaigused sõltumatus Eestis" on muuhulgas antud ülevaade kõnealuse karskuskampaania olulisimatest joontest ja iseloomustatud alkoholitarbimises aset leidnud muudatusi (Liiv 2000: 296-309). Põhjalikumalt on A. Liiv too- 
nase alkoholipoliitika mõju alkoholitarbimisele kirjeldanud 1991. aastal ilmunud artiklis "Alcohol Problems in Estonia in 1980s" (Liiv 1991: 31-38). Artiklis on aastate kaupa esitatud kõnealusel perioodil Eestis tarbitud alkoholi kogused, samuti alkoholitarbimise struktuur erinevate alkohoolsete jookide kaupa. Esitatud andmetest järeldub alkoholitarbimise tugev vähenemine karskuskampaania perioodil.

Kuid nõukogude võimu tingimustes andmeid kogudes polnud võimalik viidata enamikule kasutatud allikatest. A. Liiv on tuginenud peamiselt müügistatistikale, mille kohta on suurem osa andmeid saadud toona ilmunud poolsalajastest väljaannetest, mis olid mõeldud vaid kitsale spetsialistide ringile ametialaseks kasutamiseks. A. Liivi suuliste teadete kohaselt on tema andmetes kohati kasutatud ka üleliidulise alluvusega üksuste (sõjaväeosad ja liidulise alluvusega suurtehased) alkoholi tarbimist kajastavat statistikat, kuid neid andmeid ei onnnestunud hankida kõigi aastate kohta (Liiv 2004).

Suitsidoloog Airi Värnik on mitmes töös käsitlenud 1980. aastate keskpaiga range alkoholipoliitika mõju suitsiidide arvule (Värnik 1997a; Värnik 1997b; Värnik 1997c: 260-263; Värnik 2002: 107-115). A. Värnik on keskendunud kogu N Liidus toimunud arenguile. Alkoholitarbimise hindamisel tugineb ta nõukogude perioodil ilmunud vastavat statistikat sisaldavatele väljaannetele, mis olid mõeldud vaid kitsale inimeste ringile ametialaseks kasutamiseks. Nende allikate tõepärasust on raske kontrollida, ka pole selge, kuidas andmed saadi. A. Värniku töös esitatud andmed absoluutse alkoholi tarbimise kohta on suhteliselt sarnased A. Liivi esitatud andmetele, kuid ei kattu täielikult. Airi Värniku uurimustest järeldub, et aastatel 1985-1987 vähenes alkoholi tarbimine, mille tagajärjel harvenesid oluliselt ka suitsiidid.

Käesoleva töö eesmärgiks on vaadelda 1985. aastal alanud üleliidulise karskuskampaania arenguid Eesti NSVs ja toonase alkoholipoliitika tagajärgi. Peamiseks sihiks on uurida 1980. aastate alkoholitarbimist ja selle struktuuri Eestis, leidmaks vastuseid, kas 1985. aastal alanud uue alkoholipoliitika tagajärjel alkoholitarbimine vähenes, kas ja millised muutused toimusid alkohoolsete jookide tarbimise struktuuris (st kuidas muutus erinevate alkohoolsete jookide osa tarbitavast alkoholist) ja kui tõenäoliseks võib pidada illegaalse alkoholi osa suurenemist.

Riikliku alkoholipoliitika iseloomustamisel on tuginetud peamiselt NLKP keskkomitee otsustele, NSV Liidu ning Eesti NSV seadusandvate ja täidesaatvate võimuorganite vastu võetud seadustele ning määrustele, mis on publitseeritud NSVL Ülemnõukogu ja Valitsuse Teatajate ning Eesti NSV Ülemnõukogu ja Valitsuse Teatajate vastavates aastakäikudes. Samas on varasemate uurijate tööde põhjal käsitletud selliseid alkoholipoliitikat puudutavaid tegevuskavu, millele avalikes dokumentides ei viidatud. 
Alkoholitarbimise hindamiseks on kasutatud ENSV Statistika Keskvalitsuse ametkondlikke aruandeid NSV Liidu Statistika Keskvalitsusele alkoholi müügi kohta Eestis (ERA, f R-1969, n 4, s 809, 835, 863, 889, 911, 939, 964, 1014, 1060, 1132, 1179). Nimetatud aruanded ei kuulunud laiemale levitamisele ega publitseerimisele, vaid olid mõeldud ainult ametialaseks kasutamiseks. Nendes kasutatud andmed saadi müügiorganisatsioonidelt ja need pidid olema vastavuses alkoholijookide tootmise, kaubastamise ja transpordiga tegelevate organisatsioonide aruannetega ning näivad seetõttu usaldusväärsed. Aruanded ei kajasta küll alkoholi tarbimist kogu tollase Eesti NSV territooriumil, välja jäi alkoholi müük liidulise alluvusega üksustes sõjaväeosades ja liidulise alluvusega tehastes - asuvates kauplustes.

Lisaks müügistatistikale on kasutatud ka muid alkoholitarbimisega teatavas seoses olevaid näitajaid, nagu fataalsete alkoholimürgistuste arv ja alkoholipsühhooside esinemissagedus. Nimetatud näitajad on kaasatud, hindamaks illegaalse alkoholi laiema leviku tõenäosust legaalse alkoholi müügi kitsenedes. Alkoholipoliitika tagajärgede iseloomustamiseks on esitatud teisigi rahvatervise seisukohalt olulisi näitajaid, milliseid võib seostada alkoholi tarbimisega - suitsiidide ja vigastussurmade arvu. Fataalsete alkoholimürgistuste, enesetappude ja vigastussurmade arvud pärinevad Eesti suremusatlasest; alkoholipsühhooside arv tugineb Anti Liivi esitatud andmetele (Baburin \& Gornoi \& Leinsalu \& Rahu 1997; Liiv 2000: 296-309).

\section{Aastate 1985-1987 alkoholipoliitika}

\subsection{Uue alkoholipoliitika eellugu ja põhjused}

Uus alkoholipoliitika ei alanud tühjalt kohalt, N Liidu varasema ajaloo käigus oli kõrgeimal riiklikul tasemel korduvalt teadvustatud ühiskonnas levinud liigjoomise ohtlikku ulatust ja püütud probleemi erinevate administratiivsete vahenditega ohjeldada. Tõsist vajadust piirata elanikkonna alkoholitarbimist hakati mõistma siiski üsna hilja, alles siis, kui ilmnes mitmete rahvatervisenäitajate paigalseis ja allakäik (Suny 1998: 440).

Teise maailmasõja järel, 1950.-1960. aastail valitses NSV Liidus väga liberaalne alkoholipoliitika, alkohol oli laialdaselt kättesaadav igas toidupoes, kangeid jooke müüdi ka paljudes kioskites. Sarnaselt enamiku oluliste poliitiliste algatuste ja programmidega sõltus ka Eesti NSV alkoholipoliitika Moskva suunistest. Sarnaselt üleliiduliste arengutega kasvas 1960. aastail koos elatustaseme mõningase tõusuga ka Eestis alkoholi tarbimine ja alkoholism hakkas kujunema tõsiseks sotsiaalseks probleemiks (Kuddo 1988: 8; Liiv 2000: 300). Vastuseks alkoholismi laiemale levikule tehti algust alkohoolikute tasuta avahoolduse, haiglaravi ja sundraviga. 1972. ja 1978. aastal 
tehti NSV Liidus esimesed tõsisemad katsed karmistada riiklikku alkoholipoliitikat. Üleliiduliste algatuste raames püüti ka Eesti NSVs riikliku poliitikaga alkoholi tarbimist piirata. 1972. aastal võeti riiklikul tasemel vastu mitmeid üleliidulistel analoogidel põhinevaid seadusi ja määrusi, millega kehtestati senisest rangemaid müügipiiranguid ja tõhustati karskuspropagandat. Samuti laiendati narkoloogiliste raviasutuste võrku (ENSV Ülemnõukogu Presiidiumi 30. juuni 1972 seadlus joomise ja alkoholismivastase võitluse tugevdamise abinõude kohta). Toonased katsed alkoholitarbimist piirata soikusid peagi. 1978. aastal üritati mainitud meetmetega veel kord joomarluse kasvu aeglustada, kuid seegi algatus vaibus tasapisi. Ei 1972. ega 1978. aasta muudatused alkoholipoliitikas andnud loodetud tulemusi ja tegelikkuses jätkus 1970. aastatel alkoholitarbimise kasv (Liiv 2000: 301).

1982. aastal tõstatas ülikõrge alkoholitarbimise küsimuse teravalt päevakorda tollal veel KGB esimehe ametis töötav Juri Andropov, kes sama aasta mais pöördus Leonid Brežnevi ja teiste NLKP KK Poliitbüroo liikmete poole kirjaga, milles toodi esile enneolematult kõrge alkoholitarbimise ohtlikkus riigi ja ühiskonna edasisele toimetulekule. Probleemi lähemaks uurimiseks moodustati vastav komisjon, mis esitas sügiseks ettepanekud alkoholitarbimise piiramiseks. Alkoholimüügi järsu vähendamise asemel soovitati komisjoni aruandes alustada lahjade jookide osa suurendamisest ning alkoholivabade einelaudade ja kohvikute võrgu laiendamisest. Tõenäoliselt kavatseti neid ettepanekuid arvestada, kuid L. Brežnevi peatse surma tõttu jäid komisjoni soovitatud meetmed rakendamata. Peagi suri ka küsimusega tegelnud komisjoni esimees ja tema ametijärglane soovitas uueks riigijuhiks saanud Juri Andropovil, kooskõlas viimase ootustega, rakendada alkoholismi piiramiseks rangemaid abinõusid. Soovitatud meetmete elluviimisega tehti ka algust, kuid J. Andropovi peatne surm katkestas kampaania edasise arengu (Ženkovitš 1999: 344-345).

1985. aastal NSV Liidu etteotsa tõusnud Mihhail Gorbatšovi peamiseks eesmärgiks kujunes suurriigi väljatoomine valitsevast majanduslikust kitsikusest. J. Andropovi eeskujul seadis uus riigijuht esialgseks sihiks süsteemi senisest paremini ja efektiivsemalt tööle rakendamise. Sel eesmärgil andis vastne parteiliider täiskäigu ka alkoholivastasele võitlusele, mida mitmed eelkäijad olid planeerinud juba kümnendi algusest peale, kuid erinevatel põhjustel lõplikult teostamata jätnud.

\subsection{5. aastal algatatud üleliidulise alkoholipoliitika põhijooned}

Üleliidulise karskuskampaania stardipauguks sai NLKP keskkomitee 7. mai 1985 otsus "Abinõudest joomarlusest ja alkoholismist jagusaamiseks", millega pandi paika uue alkoholipoliitika põhiprogramm ning määratleti kasu- 
tatavate õiguslike, administratiivsete ja sotsiaalmajanduslike abinõude põhijooned. Samal päeval andis NSV Liidu ministrite nõukogu välja määruse "Abinõudest joomarlusest ja alkoholismist jagusaamiseks ning puskariajamise likvideerimiseks" ja 16. mail võttis NSV Liidu Ülemnõukogu Presiidium vastu seadluse "Joomarluse vastu võitlemise tõhustamisest". Nimetatud aktid täpsustasid uue alkoholipoliitika elluviimiseks kasutatavaid meetmeid, vormistades NLKP keskkomitee otsuses nimetatud suunised konkreetsete ülesannete ja õigusnormidena. 1985. aasta septembris võttis NLKP keskkomitee vastu veel teisegi karskuse edendamist käsitleva otsuse ("Abinõudest joomarlusest ja alkoholismist jagusaamiseks"), mis paljuski kordas 7. mai dokumendi põhimõtteid. Otsus kinnitas uue alkoholipoliitika jätkumist täie rangusega, eitades võimalust mis tahes mööndusteks või järeleandmisteks kehtestatud piirangutes. Tuginedes eelloetletud liiduülestele normatiividele, anti liiduvabariikides välja vastavasisulised õigusaktid, mis sisuliselt kopeerisid üleliidulisi analooge (NSV Liidu ministrite nõukogu 7. mai 1985 määrus nr 410 "Abinõudest joomarlusest ja alkoholismist jagusaamiseks ning puskariajamise likvideerimiseks"; NSV Liidu Ülemnõukogu Presiidiumi 16. mai 1985 seadlus joomarlusevastase võitluse tõhustamise kohta; NLKP keskkomitee 18. septembri 1985 otsus "Abinõudest joomarlusest ja alkoholismist jagusaamiseks").

NLKP keskkomitee otsuses sätestatud kurss alkoholi tarbimise tunduvale piiramisele määras nii üleliiduliste kui ka liiduvabariikide seadusandva ja täidesaatva võimu organite tegutsemissuuna. Partei otsuse põhjal üleliiduliste võimuorganite kehtestatud seadused ja määrused andsid vabariiklikele institutsioonidele konkreetsed tegevusjuhised.

NSV Liidu ministrite nõukogu määrusega kohustati liiduvabariikide ja kohtade täitesaatva võimu esindajaid teostama partei määratud karskuskampaaniat ja anti täpsemad instruktsioone selle läbiviimiseks. Nimetatud dokumendi põhjal võttis Eesti NSV ministrite nõukogu 28. mail 1985 vastu määruse "Joomarlusest ja alkoholismist jagusaamise ning puskariajamise likvideerimise kohta", mis sätestas alkoholipoliitika rakendamise korra Eestis, andes kohalikele täidesaatva võimu erinevatele üksustele konkreetsed ülesanded ja tegevusjuhised.

Uue alkoholipoliitika elluviimiseks vajalikuks peetavad muudatused õigusnormides kehtestati Eesti NSVs peamiselt NSVL Ülemnõukogu Presiidiumi seadluse põhjal 1985. aasta 28. mail vastu võetud ENSV Ülemnõukogu Presiidiumi seadluses joomarluse ja alkoholismivastase võitluse tugevdamise ning puskariajamise likvideerimise abinõude kohta. Sisuliselt kopeerisid vabariiklikud õigusaktid üleliidulisi seadusi ja määrusi.

1985. aastal alanud karskuskampaanias oli oluline roll vastavasisulisel propagandal. Eesti NSV Riiklikku Kirjastuse, Polügraafia ja Raamatukau- 
banduse Komiteed kohustati suurendama vastavasisuliste trükiste hulka ja parandama nende kvaliteeti. Samuti kohustati Eesti NSV Riiklikku Kinokomiteed ning Eesti NSV Riiklikku Televisiooni ja Raadiokomiteed suurendama karskust propageerivate filmide ning tele- ja raadiosaadete hulka (Eesti NSV ministrite nõukogu 28. mai 1985 määrus nr 313 "Joomarlusest ja alkoholismist jagusaamise ning puskariajamise likvideerimise abinõude kohta"). Tulemuseks oli karskust propageerivate ja alkohoolsete jookide tarbimise kahjulikkust selgitavate artiklite, pisitrükiste, tele- ja raadiosaadete rohkus. Selline alkoholivastane propagandalaine massimeedias oli kaasnenud ka varasemate alkoholipoliitika karmistamise katsetega 1970. aastatel ja samuti 1980. aastate alguses. 1985. aastal alanud propagandalöök oli eelnenutest siiski veidi võimsam (Liiv 2000: 296-309).

Erinevalt varasemast karskuspropagandast lõdvendati 1985. aastal alanud karskuskampaania käigus veidi tsensuuri, lubades massiteabekanalites senisest avameelsemat arutelu alkoholitarbimise laia leviku küsimustes. Esmakordselt pikkade aastate jooksul lubati eestikeelses ajakirjanduses avaldada statistikat alkoholi tarbimise kohta (Liiv 2000: 296-309). Aastast 1987 publitseeriti ka avalikes statistikakogumikes mõningaid andmeid alkohoolsete jookide müügi kohta, siiski erinesid viimastes esitatud numbrid statistikakomitee ametlikes aruannetes antud arvudest (Andrejeva \& Zamahhin 1988: 266; Andrejeva \& Zamahhin 1989: 270; ERA, f R-1969, n 4, s 964, L 16p, s 1014, L 47p, s 1060, L 25p).

Karskuse levikut loodeti soodustada igasuguse alkoholi tarbimise keelamisega avalikel üritustel ja pidustustel. Täielikuks tabuks muutus alkohoolsete jookide pakkumine asutustes ja organisatsioonides korraldatud pidustustel, sealhulgas peeti lubamatuks ka pokaali vahuveini ametlikel bankettidel ja vastuvõttudel (Eesti NSV ministrite nõukogu 28. mai 1985 määrus $\mathrm{nr} 313$ "Joomarlusest ja alkoholismist jagusaamise ning puskariajamise likvideerimise abinõude kohta").

Karskusaate propageerimiseks loodi Moskvas 1985. aasta 25. septembril Üleliiduline Vabatahtlik Karskusühing, liiduvabariikides asusid tegutsema selle koosseisu kuuluvad algorganisatsioonid. Muidugi polnud tegu kodanikualgatuse korras tekkinud ühinguga, vaid riiklikult organiseeritud liikumisega. Riiklikul tasandil organiseeritud üleliiduline karskusühing oli NSV Liidus uus nähtus (kui mitte arvestada maailmasõdadevahelisel ajal tegutsenud organisatsioone). Karskusühingu algorganisatsioonid loodi töö- ja õppekohajärgselt ettevõtetes, asutustes, kolhoosides, sovhoosides ja ka õppeasutustes. Algorganisatsioonid pidid tegelema karskete eluviiside propageerimisega vastavas ettevõttes või organisatsioonis ning aitama kaasa töötajate vaba aja sisustamisele (vt Üleliidulise Vabatahtliku Karskusühingu 
põhikiri). Eestis moodustati 1986. aasta teiseks pooleks 1638 karskusühingu algorganisatsiooni, mis koondasid üle 28000 liikme. Nagu arvata, jäi suhtumine kohustuslikus korras loodud karskusühingusse leigeks, suure osa karskusühingusse kuulujate liikmestaatus oli pigem formaalne ning siiraid karskusaate levitajaid ja kaitsjaid oli nende hulgas vähe (Liiv 2000: 304).

Alkoholismi leviku tõkestamiseks olid 1972. aasta seadluse alusel loodud spetsiaalsed institutsioonid - joomarlusega võitlemise komisjonid - mis tegutsesid Eesti NSV ministrite nõukogu, rajoonide, linnade ja linnarajoonide rahvasaadikute nõukogude täitevkomiteede osana, kuid neid võis moodustada ka alevite ja külade rahvasaadikute nõukogude täitevkomiteede juures (Eesti NSV Ülemnõukogu Presiidiumi 30. juuni 1972 seadlus joomise ja alkoholismi vastase võitluse tugevdamise abinõude kohta; Eesti NSV Ülemnõukogu Presiidiumi 30. märtsi 1973. aasta seadlus joomarlusega võitlemise komisjonide põhimääruse kinnitamise kohta). Eesti NSV Ülemnõukogu Presiidiumi 1985. aasta seadlus kordas üle kõnealuste komisjonide ülesanded, uuendusena võimaldas seadlus moodustada komisjone ka ettevõtetes, asutustes ja organisatsioonides ning 1986. aasta alul uuendati nimetatud komisjonide põhimääruse teksti, täpsustades ettevõtete ja asutuste vastavate komisjonide funktsioone. Lisaks võeti viimaste tegevuse täpsemaks sätestamiseks vastu veel eraldi põhimäärus (Eesti NSV Ülemnõukogu Presiidiumi 10. jaanuari 1986 seadlus joomarlusega võitlemise komisjonide põhimääruse kinnitamise kohta; Eesti NSV Ülemnõukogu Presiidiumi 28. mai 1985 seadlus joomarluse ja alkoholismivastase võitluse tugevdamise ning puskariajamise likvideerimise abinõude kohta).

Rahvasaadikute nõukogude juures tegutsevate joomarlusega võitlemise komisjonide ülesandeks oli välja töötada ja rakendada abinõusid karskuse propageerimiseks ja alkoholismi ärahoidmiseks. Samuti oli nimetatud komisjonidel õigus kontrollida siseasjade- ja tervishoiuorganite vastavat tegevust ning alkohoolsete jookide müügieeskirjade täitmist kaubandus- ja toitlustusettevõtetes. Töökollektiivides tegutsevate joomarlusega võitlemise komisjonide funktsiooniks oli karskust propageeriva teavitustöö korraldamine konkreetse ettevõtte või asutuse piires, samuti pidasid komisjonid arvestust kollektiivi kuuluvate sundravil olnud alkohoolikute üle. Töökollektiivide joomarlusega võitlemise komisjonidel oli õigus läbi vaadata töötajate pisemate alkoholi kuritarvitamisega seotud õigusrikkumiste materjale (seda juhul, kui vastav organ, kel oli õigus määrata karistusi nimetatud rikkumiste eest, andis läbivaatamiseks loa) ning komisjon võis rakendada väiksemaid karistusi - avaldada hoiatuse, noomituse või määrata rahatrahvi kuni 50 rubla (Eesti NSV Ülemnõukogu Presiidiumi 10. jaanuari 1986 seadlus joomarlusega võitlemise komisjonide põhimääruse kinnitamise kohta; Ees- 
ti NSV Ülemnõukogu Presiidiumi 28. mai 1985 seadlus joomarluse ja alkoholismivastase võitluse tugevdamise ning puskariajamise likvideerimise abinõude kohta).

Uue alkoholipoliitika planeerijad mõistsid, et teavitustööst ja alkohoolsete jookide kättesaadavuse kitsendamisest jääb väheks. Teadvustati vajadus pakkuda napsitamise alternatiivina erinevaid võimalusi lõõgastumiseks ja vaba aja veetmiseks. Jõudeaja senisest parema sisustamise võimaldamist oli rõhutatud ka 1970. aastate alkoholipoliitika karmistamise käigus (Eesti NSV ministrite nõukogu 10. juuli 1972 määrus nr 334 “Joomise ja alkoholismi vastase võitluse tugevdamise abinõude kohta"), kuid 1985. aasta alkoholipoliitika alusdokumendid olid selles küsimuses varasemast märksa põhjalikumad ja täpsemad. Vastukaaluks alkohoolsete jookide müügi olulisele piiramisele nägi 1985. aasta määrus ette alkoholivabade kohvikute ja einelaudade võrgu laiendamist ning olemasolevate kvaliteedi parandamist. Eesti NSV Plaanikomiteed, Eesti NSV Ehituskomiteed ja teisi institutsioone kohustati aastate 1986-1990 majandusarengu plaanis kavandama kultuuri- ja spordirajatiste ning toitlustusettevõtete ehitamist, samuti peeti vajalikuks olemasolevate kultuuri- ja spordirajatiste edasiarendamist. Eesti NSV Elamu ja Kommunaalmajanduse Ministeeriumi süsteemi elamuekspluatatsiooniorganisatsioonide tuludest otsustati eraldada $3 \%$ spordi arendamiseks ja spordirajatiste ehitamiseks. Eesti NSV Plaanikomiteed, Eesti NSV Varustuskomiteed ja Eesti NSV Kaubandusministeeriumi kohustati tagama kultuurikaupade ja muude mitmete hobidega tegelemiseks vajalike vahendite (nt lukksepa- ja puusepatööriistade, autode ja mootorrataste varuosade jne) laialdasemat müüki kaubanduses (Eesti NSV ministrite nõukogu 28. mai 1985 määrus nr 313 "Joomarlusest ja alkoholismist jagusaamise ning puskariajamise likvideerimise abinõude kohta”).

Ennetavate meetmete hulka võib lugeda ka korralduse laiendada töötasu väljamaksmist pankade, st tollaste hoiukassade kaudu. Samuti nõudsid uued seadused igasuguste rahaliste preemiate väljamaksmist ainult koos järgmise palgaga (Eesti NSV ministrite nõukogu 28. mai 1985 määrus nr 313 "Joomarlusest ja alkoholismist jagusaamise ning puskariajamise likvideerimise abinõude kohta").

Ilmselt lootuses vähendada koduveini valmistamist, kohustati Eesti NSV Aiandusministeeriumi, Eesti NSV Toiduainetetööstuse Ministeeriumi, ETKVLi, Eesti NSV Agrotööstuskoondist ja kohalikke täitevkomiteesid suurendama potentsiaalse tooraine, puuviljade ja marjade ülejääkide kokkuostu nii ühismajanditelt kui ka eraisikutelt (Eesti NSV ministrite nõukogu 28. mai 1985 määrus nr 313 "Joomarlusest ja alkoholismist jagusaamise ning puskariajamise likvideerimise abinõude kohta”). 
Loomulikult leidis rakendamist ka klassikalisim võte alkoholitarbimise ohjeldamisel - joovastavate jookide kättesaadavuse piiramine. Karmistati müügipiiranguid ning vähendati alkohoolsete jookide tootmist ja jaekaubandusse suunatava alkoholi hulka. Samuti tõsteti järsult joovastavate jookide hindu ning peagi kehtestati inimese kohta kindel norm, mille ulatuses üldse võis alkoholi osta. Avalikkuses levitatud programmides ei täpsustatud, kui palju kavatsetakse vähendada alkoholi tootmist ja müüki, samuti ei reklaamitud alkohoolsete jookide hinnatõusu. Ametlikes plaanides oli aga eesmärgiks seatud saavutada 1990. aastaks alkoholi müügi vähenemine viiele liitrile absoluutsele alkoholile elaniku kohta (Kuddo 1988: 6).

Eesti NSV ministrite nõukogu 28. mail 1985 vastu võetud määrusega "Joomarlusest ja alkoholismist jagusaamise ning puskariajamise likvideerimise kohta" viidi alkohoolsete jookide müügieeskirjadesse järgmised muudatused. Keelati alkoholi müük alla 21-aastastele isikutele (senine vanusepiir oli olnud 18 eluaastat). Jaekaubandusettevõtetes lubati alkohoolsete jookide müüki tööpäeviti kell 14-21, puhke- ja pidupäevadel kell 11-17. Toitlustusettevõtted, millel oli luba alkohoolsete jookide müügiks, võisid alkoholi müüa tööpäevadel alates kella 14st ning puhke- ja pidupäevadel kella 11st kuni ettevõtte sulgemiseni (Eesti NSV ministrite Nõukogu 28. mai 1985 määrus nr 313 "Joomarlusest ja alkoholismist jagusaamise ning puskariajamise likvideerimise abinõude kohta"). Kirjeldatud ajalised piirangud olid senisest rangemad, kuid mitte enneolematud. Juba 1959. aastast oli keelatud viina müük enne kella 10 hommikul, 1972. aastast alates oli kõigi 30protsendiliste ja kangemate alkohoolsete jookide müük jaekaubanduses keelatud enne kella 11 hommikul ja pärast kella 19 õhtul. 1973. aastast keelati 30-protsendiliste ja kangemate alkohoolsete jookide müük püha- ja pidupäevadel ning laupäeviti võis neid müüa kell 11-14 (Eestimaa Kommunistliku Partei keskkomitee ja Eesti NSV ministrite nõukogu 26. jaanuari 1959 määrus $\mathrm{nr} 23$ "Joomise vastu peetava võitluse tõhustamisest ning korra loomisest kangete alkohoolsete jookide kaubastamisel").

1985. aasta määrusega keelati alkohoolsete jookide müük kaubandusettevõtetes, mis asusid tootmisettevõtete ja ehituste, õppeasutuste, ühiselamute, lasteasutuste, haiglate, sanatooriumite, puhkekodude, raudteejaamade, sadamate ja lennujaamade, kultuuri- ja etendusasutuste läheduses ning töötajate kogunemis- ja puhkepaikades, samuti väikejaekaubandusvõrgus. Lasteasutuste vahetus läheduses oli alkohoolsete jookide müük keelatud juba 1972. aastal, teistes nimetatud kohtades oli 1972. aastast olnud keelatud 30\%liste ja kangemate alkohoolsete jookide müük. 1976. aastast oli alkoholi müük keelatud spordivõistlustel, laulupidudel ja muudel massiüritustel (Eesti NSV ministrite nõukogu 10. juuli 1972 määrus nr 334 “Joo- 
mise ja alkoholismi vastase võitluse tugevdamise abinõude kohta"; Eesti NSV ministrite nõukogu 23. septembri 1976 määrus nr 430 "Eesti NSV ministrite nõukogu 10. juuli 1972. aasta määrus nr 334 punkti 2 alapunkti 2 muutmise kohta").

1985. aasta määruses märgiti plaani hakata lähemas tulevikus viina ja kangeid piiritusjooke müüma üksnes spetsiaalsetes kauplustes või toidukaupluste spetsiaalsetes osakondades. Katseid selles osas oli tehtud varemgi: 1972. aasta ENSV ministrite nõukogu määrus käskis erinevatel institutsioonidel alustada linnades ja rajoonikeskustes üleminekut 30-protsendiliste ja kangemate alkohoolsete jookide müümisele ainult spetsiaalsetes kauplustes. Üleminek tulnuks lõpule viia 1974. aastal (Eesti NSV ministrite nõukogu 28. mai 1985 määrus nr 313 "Joomarlusest ja alkoholismist jagusaamise ning puskariajamise likvideerimise abinõude kohta").

Uue alkoholipoliitika raames vähendati ka alkohoolsete jookide tootmist. 1987. aastaks lõpetati täielikult puuvilja-marjaveinide tootmine, mistõttu suleti mõningad kohalikud veinitehaseid, ülejäänud orienteeriti ümber mahlade ja muu sellesarnase tootmisele. Seoses jaekaubandusse jõudvate alkohoolsete jookide koguse vähendamisega kehtestati neile peagi kindlad müüginormid. Talongide alusel oli igal täiskasvanul võimalus osta pool liitrit viina kuus. Siiski võimaldas talongisüsteem erandeid, juubeli või matuste puhul võis vastavate dokumentide ettenäitamisel osta tavalisest kuunormist märgatavalt suurema koguse alkohoolseid jooke (Värnik 1997b: 76). Karskuskampaania ajal tõusis ka alkoholi hind, mõnede artiklite puhul see isegi mitmekordistus (Wasserman \& Värnik \& Eklund 1998: 26-33).

Karskuskampaania raames pöörati tähelepanu ka alkohoolikute raviks mõeldud meditsiinilise abi parandamisele. Eesti NSV ministrite nõukogu 28. mail 1985 vastu võetud määrusega "Joomarlusest ja alkoholismist jagusaamise ning puskariajamise likvideerimise kohta" kohustati ENSV Tervishoiuministeeriumi aastate 1986-1987 jooksul laiendama alkohoolikute raviasutuste võrku. Tallinnas tuli avada isemajandav narkoloogiakabinet alkohoolikute anonüümseks raviks. Samuti pidi tervishoiuministeerium kiirendama alkohoolikute sundravi asutuste võrgu arendamist, mis olid mõeldud raskeid kaasnevaid haigusi (nt tuberkuloos) põdevatele patsientidele. Narkoloogiatalituse koosseisus tuli avada erikabinet karskuspropaganda korraldamiseks ettevõtetes ja asutustes ning profülaktilise meditsiinilise abi andmiseks alkohoolikuile, samuti oli vaja avada kabinetid selliste inimeste anonüümseks raviks. ENSV Kõrg- ja Keskhariduse Ministeeriumi kohustati vastavalt narkoloogiaasutuste võrgu laienemisele tagama vajaliku hulga narkoloogide ja narkoloogiavelskrite ettevalmistamine (Eesti NSV ministrite nõukogu 28. mai 1985 määrus nr 313 "Joomarlusest ja alkoholismist jagu- 
saamise ning puskariajamise likvideerimise kohta"; Liiv 1990a: 49; 1991b: 94-99).

ENSV Ülemnõukogu Presiidiumi seadlus kordas üle juba varem tuntud sundravi võimaluse nende alkohoolikute suhtes, kes vabatahtlikust ravist on keeldunud või kui vabatahtlik ravi pole andnud soovitud tulemusi. Sundravi sellistele isikutele oli kehtestatud juba 1965. aastal (Eesti NSV Ülemnõukogu Presiidiumi 24. aprilli 1965 seadlus alkohoolseid jooke kuritarvitavate isikute sundravi ja tööga ümberkasvatamise kohta). Sundravi läbiviimiseks olid spetsiaalsed raviasutused, ravi- ja tööprofülaktooriumid. Esialgu oli sundravi kestuseks määratud 6-12 kuud, 1967. aastast alates kuni kaks aastat, 1974. aastast oli raviaeg 1-2 aastat, 1975. aastast võis seda vajadusel veel aasta võrra pikendada (Eesti NSV Ülemnõukogu Presiidiumi 25. augusti 1967 seadlus muudatuste ja täienduste tegemise kohta ENSV Ülemnõukogu Presiidiumi 1965. aasta 24. aprilli seadluses "Alkohoolseid jooke kuritarvitavate isikute sundravi ja tööga ümberkasvatamise kohta"; Eesti NSV Ülemnõukogu Presiidiumi 30. augusti 1974 seadlus muudatuste ja täienduste tegemise kohta ENSV seadusandluses seoses NSVL Ülemnõukogu Presiidiumi 25. aprilli 1974. aasta seadlusega "Võitluse tugevdamise kohta narkomaaniaga”; Eesti NSV Ülemnõukogu Presiidiumi 31. oktoobri 1975 seadlus krooniliste alkohoolikute ja narkomaanide sundravi ja tööga ümberkasvatamise kohta). Omavoliline lahkumine või põgenemine ravi- ja tööprofülaktooriumist oli algusest peale kriminaalkorras karistatav, 1983. aastast võis selle eest määrata vabadusekaotuse 6-14 kuuni (Eesti NSV Ülemnõukogu Presiidiumi 28. jaanuari 1983 seadlus täienduste ja muudatuste tegemise kohta ENSV kriminaalkoodeksis).

Kõik eelloetletud eeskirjad kehtisid 1985. aastal edasi. Ravi- ja tööprofülaktooriumisse sundravile ei saadetud kroonilisi alkohoolikuid, kes põdesid raskeid kaasnevaid haigusi, I ja II grupi invaliide, üle 60 aasta vanuseid mehi ja üle 55 aasta vanuseid naisi. 1985. aastast alates seati nimetatud isikute sundraviks sisse spetsiaalsed tervishoiu- ja hooldeasutused (Eesti NSV Ülemnõukogu Presiidiumi 18. novembri 1985 seadlus muudatuste ja täienduste tegemise kohta mõnedes ENSV seadusandlikes aktides).

Narkoloogiateenistust, meedikuid ja ka teisi institutsioone innustati ja kohustati pöörama senisest rohkem tähelepanu alkohoolikutele ning tegema kõik endast oleneva, et vastava diagnoosiga inimesed ravile suunataks. Nimetatud ülesande usinast täitmisest annab tunnistust registreeritud alkoholismijuhtumite kasv, samas kui kõik teised alkoholi tarbimist iseloomustavad näitajad langesid (Liiv 1991a: 35).

Uus alkoholipoliitika hõlmas karistuste karmistamist alkoholi tarbimise ja müügiga seotud õigusrikkumiste eest. 1. juunist 1985 jõustunud NSV Lii- 
du Ülemnõukogu Presiidiumi 16. mai 1985 seadluse joomarluse vastu peetava võitluse tõhustamisest kohaselt viidi liiduvabariikide seadusandlusesse sisse muudatused ja täiendused vastavalt nimetatud seadusele. Eesti NSV Ülemnõukogu Presiidium võttis 1985 . aasta 28. mail vastu vastava seadluse joomarluse ja alkoholismi vastase võitluse tugevdamise ning puskariajamise likvideerimise abinõude kohta, millega kohandati kohalikku seadustikku kooskõlas uue NSVL Ülemnõukogu Presiidiumi otsusega. Uue seadusega karmistati karistusi mitmesuguste alkoholiga seotud õigusrikkumiste eest, tuntavad muutused puudutasid sanktsioone tööl alkoholi pruukimist, joobeseisundis erinevate mootorsõidukite juhtimist, alkohoolsete jookidega spekuleerimist ja alaealiste alkoholi tarbimist sisaldavate rikkumiste eest.

Hoolimata esialgsetest kategoorilistest loosungitest ja väljaütlemistest partei otsustes, et võitlust alkoholiga liialdamise vastu jätkatakse kuni pahe väljajuurimiseni, jäi karskuskampaania siiski lühiajaliseks. Uut alkoholipoliitikat teostati esialgu küll enneolematult jõuliselt, kuid majanduslikud põhjused sundisid seda peatama. Alkoholi tootmise oluline vähendamine kahandas tunduvalt alkoholi müügilt saadavaid tulusid ja riigikassa poleks kannatanud eksperimendi jätkamist. Joovastavate jookide müügi vähendamise tagajärjel kaotati saamatajäänud tuludena 37 miljardit rubla (McCellan 1998: 260). Olukorra sunnil katkestati varasemad plaanid ning juba 1988. aastal sätestati ministrite nõukogu määrusega taas alkohoolsete jookide toodangu mahu suurendamine (Zenkovitš 1999: 356).

\section{Mihhail Gorbatšovi alkoholipoliitika tagajärjed}

\subsection{Alkoholitarbimine Eesti NSVs 1980. aastatel}

Elanikkonna alkoholitarbimist iseloomustab kõige täpsemalt aastas ühe inimese kohta aastas tarbitud absoluutse alkoholi kogus. Joonis 1 näitab Eestis 1980. aastail aset leidnud muudatusi alkoholi tarbimises.

Kõige rohkem tarbiti alkoholi 1981. ja 1984. aastal, üldse oli 1980. aastate esimesel poolel alkoholi tarbimine Eestis märgatavalt suurem kui kümnendi teisel poolel. Selgelt on näha alkoholi tarbimise kahanemine 1985. aasta järel. Kui aastatel 1980-1984 tarbiti inimese kohta absoluutset alkoholi 10,610,9 liitrit, siis 1985 . aastal oli vastav näitaja 9,8 liitrit, 1986 . aastal 7,5 liitrit ja 1987. aastal 6,4 liitrit. 1984. aastaga võrreldes kahanes alkoholi tarbimine 1987. aastaks 40\%. Koos alkoholismivastase võitluse raugemisega 1980. aastate lõpul kasvas alkoholi tarbimine taas, saavutamata kohe siiski kümnendi esimese poole taset (ERA, f R-1969, n 4, s 809, L 30; s 835, L 7p; s 863, 


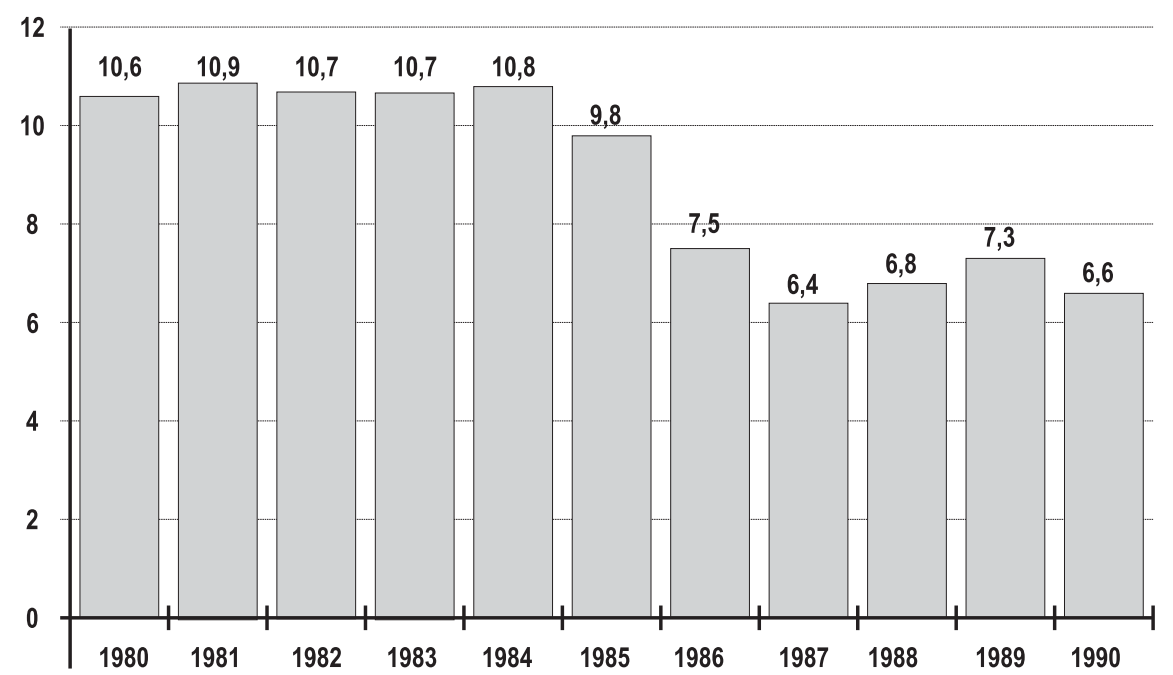

Joonis 1. Absoluutse alkoholi tarbimine elaniku kohta liitrites Eesti NSVs aastatel 1980-1990 (arvutusalused: ERA, fR-1969, n 4, s 809, 835, 863, 889, 911, 939, 964, 1014, 1060, 1132, 1179).

L 7-7p; s 889, L 5-5p; s 911, L 5p; s 939, L 5p; s 964, L 16p; s 1014, L 47p; s 1060, L 25p; s 1132, L 7p; s 1179, L 5p-6).

Oluline näitaja rahvastiku alkoholitarbimise iseloomustamisel on erinevate jookide osa kogu tarbitud absoluutsest alkoholist, täpsemalt see, kas suurema osa moodustavad kanged või lahjad alkohoolsed joogid. Kõnealusel perioodil oli Eestile iseloomulik kange alkoholi domineerimine, üle poole joodud absoluutsest alkoholist tarbiti kangete jookidena. Kangest alkoholist pruugiti enim viina ja viinatooteid; brändi ja brändijoogid moodustasid tarbitud kangest alkoholist väga väikese osa, brändijookide osa tarbitud kangest alkoholist kõikus kümnendi vältel 4,5-8\% vahel. 1980. aastate esimesel poolel oli kangete alkohoolsete jookide tarbimine märgatavalt suurem kui kümnendi teisel poolel. 1980. aastal tarbiti inimese kohta 14,7 liitrit, 1981. aastal 15 liitrit, 1982. aastal 14,2 liitrit, 1983. aastal 14,7 liitrit kangeid alkohoolseid jooke. Kõige enam joodi kangeid jooke 1984. aastal 15,4 liitrit inimese kohta. Järgnevail aastail kange alkoholi tarbimine vähenes. 1985. aastal müüdi kangeid alkohoolseid jooke 10,4\% vähem kui eelmisel aastal, 13,8 liitrit inimese kohta. Eriti tugevalt vähenes kange alkoholi tarbimine 1986. ja 1987. aastal: 1986. aasta müük kahanes eelmise aastaga võrreldes $21 \%$ ning 1987. aastal müüdi kanget alkoholi inimese kohta 8,3 liitrit, mis oli 23,9\% vähem kui 1986. ja 46\% vähem kui 1984. aastal (ERA, f R1969, n 4, s 809, L 30; s 835, L 7p; s 863, L 7-7p; s 889, L 5-5p; s 911, L 5p; s 939, L 5p; s 964, L 16p; s 1014, L 47p; s 1060, L 25p; s 1132, L 7p; s 1179, L $5 \mathrm{p}-6)$. 
Koos karskuskampaania raugemisega 1987. aastal hakkas kange alkoholi tarbimine taas suurenema, siiski jäid pruugitud kogused 1980. aastate esimese poole tasemele oluliselt alla. 1988. aastal tarbiti elaniku kohta 8,8 liitrit, 1989. aastal 9,6 liitrit ja 1990. aastal 10,3 liitrit kangeid alkohoolseid jooke. 1987. aastaga võrreldes kasvas kange alkoholi tarbimine inimese kohta 1990. aastaks 24\% (ERA, f R-1969, n 4, s 809, L 30; s 835, L 7p; s 863, L 7-7p; s 889, L 5-5p; s 911, L 5p; s 939, L 5p; s 964, L 16p; s 1014, L 47p; s 1060, L 25p; s 1132, L 7p; s 1179, L 5p-6).

Kangemate ja lahjemate alkohoolsete jookide osast kogu tarbitud absoluutses alkoholis annab ülevaate joonis 2. Aastatel 1980-1984 moodustas kange alkoholina joodud absoluutne alkohol kogu tarbitud absoluutsest alkoholist keskmiselt 55,3\%. Suhteliselt suur oli kange alkoholi osa 1984. aastal, mil kangete jookidena tarbitu moodustas kogu pruugitud absoluutsest alkoholist 57\%. 1985. aastal vähenes see vaid pool protsenti ja kasvas 1986. aastal 58,5\%ni kogu tarbitud absoluutsest alkoholist. Kuigi 1986. aastal kange alkoholi osa kogu tarbitud alkoholi hulgas suurenes, oli kangete jookide müük koguseliselt märgatavalt vähenenud. Kange alkoholi osa ajutine kasv oli tingitud mõningate lahjemate jookide, puuvilja- ja marjaveinide ning viinamarjaveinide müügi järsust vähenemisest 1986. aastal. Edaspidi kange alkoholi osa kahanes, püsides 1987. ja 1988. aastal kümnendi madalaimal tasemel - 52\% (ERA, f R-1969, n 4, s 809, L 30; s 835, L 7p; s 863, L 7-7p; s 889, L 5-5 p; s 911, L 5p; s 939, L 5p; s 964, L 16p; s 1014, L 47p; s 1060, L 25p; s 1132, L 7p; s 1179, L 5p-6).

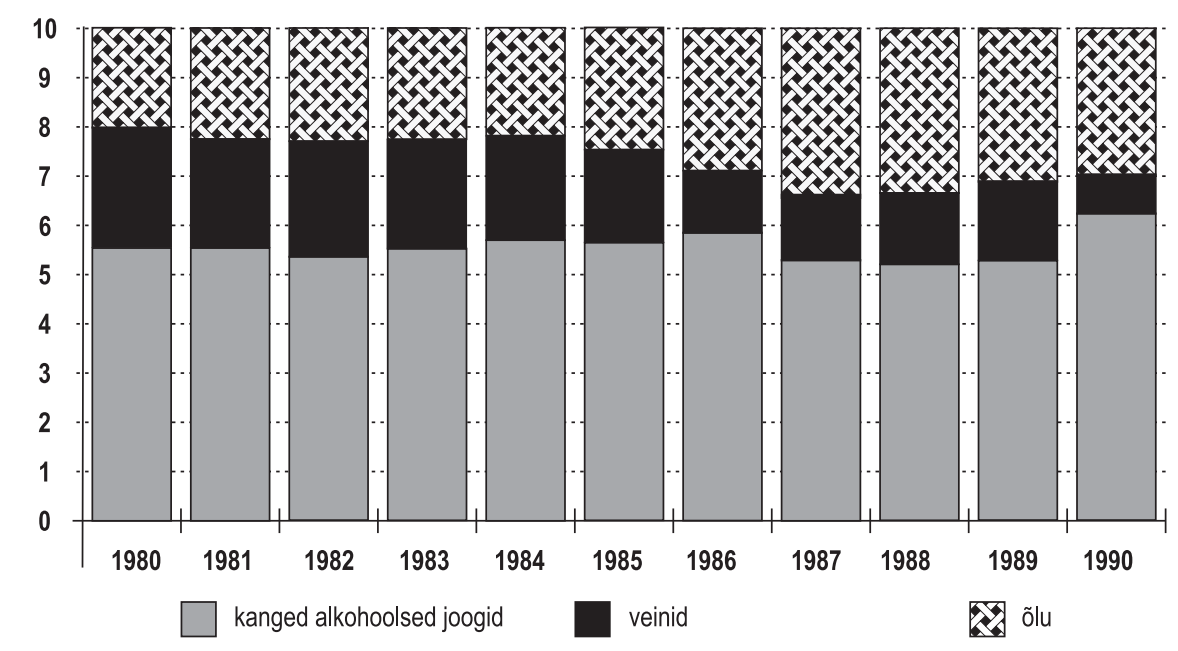

Joonis 2. Erinevate alkohoolsete jookide osa kogu tarbitud absoluutsest alkoholist ENSVs aastatel 1980-1990 (allikad ja arvutusalused: $E R A, f R-1969, n$ 4, s 809, 835, 863, 889, 911, 939, 964, 1014, 1060, 1132, 1179). 
Lahjemate alkohoolsete jookide hulka kuuluvatest veinidest väärivad eraldi esiletoomist puuvilja-marjaveinid. Need olid enamasti viinamarjaveinidest suurema alkoholisisaldusega, mitmed sordid olid piirituse lisamisega kangestatud, joogi alkoholisisaldus oli keskmiselt 16-18\%. Odavusest hoolimata tarbiti puuvilja-marjaveine siiski suhteliselt vähe, madalast kvaliteedist tingituna peeti neid pigem madalale sotsiaalsele staatusele viitavaks joogiks. 1980. aastate esimesel poolel joodi puuvilja-marjaveine keskmiselt 2,5-3 liitrit inimese kohta aastas, kõige suurem oli tarbimine 1982. aastal, mil piiritusveine joodi inimese kohta 4,2 liitrit aastas. Kümnendi esimesel poolel moodustas puuvilja-marjaveinidena tarbitud absoluutne alkohol kogu tarbitud absoluutsest alkoholist keskmiselt 5\%. Tarbimine kahanes järsult 1986. aastal, mil puuvilja-marjaveine müüdi vaid 0,6 liitrit inimese kohta, seega 64,7\% vähem kui eelmisel aastal. Tarbitud absoluutsest alkoholist moodustasid piiritusveinid 1986. aastal väikseima osa, vaid 1,8\% (ERA, f R-1969, n 4, s 809, L 30; s 835, L 7p; s 863, L 7-7p; s 889, L 5-5p; s 911, L 5p; s 939, L 5p; s 964, L 16p; s 1014, L 47p; s 1060, L 25p; s 1132, L 7p; s 1179, L 5p-6). NLKP keskkomitee otsuses nähti ette lõpetada 1988. aastaks NSV Liidus puuvilja- ja marjaveinide tootmine täielikult. Eestis kadus kõnealune jook uue alkoholipoliitika mõjul müügilt juba 1987. aastaks (ERA, f. R1969, n 4, s 1014, L 47p).

Viinamarjaveine tarbiti 1980. aastail oluliselt rohkem kui puuvilja-marjaveine. Eriti ohtralt pruugitigi naturaalveine kümnendi alguses. Enim müüdi neid 1980. aastal, edaspidi vähenes tarbimine igal aastal. Sarnaselt kangete alkohoolsete jookide tarbimisega toimus 1982. aastal viinamarjaveinide müügis veidi järsem kahanemine, ilmselt tingituna Andropovi-aegsetest alkoholipoliitika karmistamise katsetest. Samas kahanes viinamarjaveinide müük erinevalt kangetest alkohoolsetest jookidest edaspidigi sujuvalt, uut suurenemist 1984. aasta paiku ega edaspidi ei tulnud. Ka vähenes 1980. aastate esimesel poolel naturaalveinide osa tarbitud absoluutsest alkoholist, 1980. aastal oli see näitaja 18,1\%, 1984. aastal 14\% (ERA, f R-1969, n 4, s 809, L 30; s 835, L 7p; s 863, L 7-7p; s 889, L 5-5p; s 911, L 5p; s 939, L 5p; s 964, L 16p; s 1014, L 47p; s 1060, L 25p; s 1132, L 7p; s 1179, L 5p-6).

Karmi alkoholipoliitika mõjul kahanes 1985 . aastal viinamarjaveinide tarbimine märgatavamalt, müük vähenes eelmise aastaga võrreldes $18 \%$. Veelgi järsemalt langes viinamarjaveinide tarbimine 1986. aastal, mil müük vähenes üle 50\%. Kahanes ka viinamarjaveinide osa kogu tarbitud absoluutse alkoholi kogusest, 1985. aastal moodustasid viinamarjaveinid sellest 12,7\%, 1986. aastal vaid 8,3\%. Viinamarjaveinide ja puuvilja-marjaveinide kahanemise arvel kasvas õlle, aga ka kange alkoholi osa kogu tarbitud absoluutse alkoholi kogusest. Karskuskampaania raugedes hakkasid 1987. aastast ala- 
tes viinamarjaveini müüginumbrid taas kasvama, jäädes siiski varasemaga võrreldes tagasihoidlikuks ja ületamata 1985. aasta taset (ERA, f R-1969, n 4, s 809, L 30; s 835, L 7p; s 863, L 7-7p; s 889, L 5-5p; s 911, L 5p; s 939, L 5p; s 964, L 16p; s 1014, L 47p; s 1060, L 25p; s 1132, L 7p; s 1179, L 5p-6).

Vahuveine, sarnaselt brändile, müüdi kogu kümnendi jooksul väikestes kogustes - ilmselt oli tegemist defitsiitse ja raskesti kättesaadava joogiga. Vahuveinide tarbimise struktuur oli erinev teiste alkohoolsete jookide omast. Kõige vähem tarbiti vahuveine 1980. aastate alguses, samas oli teiste alkohoolsete jookide tarbimine 1980. aastate esimesel poolel tunduvalt suurem kui kümnendi teisel poolel. 1985. aastal vähenes vahuveinide tarbimine $15 \%$ võrreldes eelmise aastaga, kuid 1986. aasta müüginumbrite kahanemine oli väike võrreldes teiste alkoholiliikide müügi vähenemisega. Vahuveinide osa kogu tarbitud absoluutse alkoholi hulgas muutus 1984. aastaga võrreldes 1985. ja 1986. aastal vähe, samas kui ülejäänud veinisortide osa kogu tarbitud alkoholist vähenes nimetatud aastail märgatavalt. 1987. aastast hakkas vahuveini tarbimine taas suurenema (ERA, f R-1969, n 4, s 809, L 30; s 835, L 7p; s 863, L 7-7p; s 889, L 5-5p; s 911, L 5p; s 939, L 5p; s 964, L 16p; s 1014, L 47p; s 1060, L 25p; s 1132, L 7p; s 1179, L 5p-6).

Enimmüüdud alkohoolne jook läbi 1980. aastate oli õlu (teisel kohal oli aastail 1980-1982 viinamarjavein, järgnesid viin ja viinatooted). Toonane õlu oli üsna lahja, keskmise kangusega 4\%. Tänapäeval levinud kangestatud õlut ei tuntud, tegemist oli ainult naturaalsel kääritamisel saadud joogiga. Madala alkoholisisalduse tõttu pöörati õlle tarbimise piiramisele uue alkoholipoliitika raames vähem tähelepanu, põhirõhk oli suunatud kangemate jookide pruukimise vähendamisele. Kui kõigi teiste alkohoolsete jookide müük 1985. aastal suuremal või vähemal määral kahanes, kasvas õlle müük samal ajal kümnendi kõrgeimale tasemele. 1985. aastal tarbiti inimese kohta 60,7 liitrit õlut, kogu tarbitud absoluutsest alkoholist moodustas õlu ligikaudu veerandi. Järgmisel aastal vähenes õlle müük $11 \%$, kuid enamiku teiste alkohoolsete jookide (välja arvatud vahuvein ja brändi) müüginumbrid vähenesid oluliselt rohkem. Õlle osa kogu tarbitud absoluutse alkoholi hulgas kasvas perioodil 1985-1987 ligikaudu 10\% (ERA, f R-1969, n 4, s 809, L 30; s 835, L 7p; s 863, L 7-7p; s 889, L 5-5p; s 911, L 5p; s 939, L 5p; s 964, L 16p; s 1014, L 47p; s 1060, L 25p; s 1132, L 7p; s 1179, L 5p-6).

\subsection{Alkoholipoliitika mõju tervisenäitajatele}

Igasuguseid alkoholipoliitika karmistamise katseid on sageli kritiseeritud väitega, et vastukaaluks riigipoolsetele müügipiirangutele laieneb illegaalse alkoholi valmistamine ja müük. Et eeltoodud alkoholi tarbimist iseloo- 
mustavad arvud tuginevad legaalse alkoholi müügi statistikale, pole nende põhjal võimalik järeldada, kas ja kui palju oli levinud illegaalse alkoholi ja surrogaatide tarvitamine.

Surmaga lõppenud alkoholimürgistuste arv ja elanikkonna alkoholitarbimine on omavahel seotud ning fataalsete alkoholimürgistuste esinemissageduse põhjal võib ligikaudselt hinnata elanikkonna alkoholitarbimist (Kaasik 2002: 96-107). Seega võimaldab alkoholimürgistuste arvu kõrvutamine legaalse alkoholi tarbimistrendidega ligikaudu hinnata illegaalse alkoholi ja eriti surrogaatide pruukimise levikut. Võrreldes alkoholimürgistuste esinemise sagedust legaalse alkoholi tarbimisega, ilmneb mõlema näitaja peamiste arengute kokkulangemine. Fataalsete alkoholimürgistuste hulk püsis 1980. aastate esimesel poolel märgatavalt suuremana kui kümnendi teisel poolel (joonis 3). Ilmselt vähenes seoses uue alkoholipoliitikaga aastail 1985-1986 surmaga lõppenud alkoholimürgistuste arv. Võrreldes 1984. aastaga vähenes fataalsete alkoholimürgistuste arv 100000 inimese kohta 1986. aastaks 45\%, absoluutse alkoholi tarbimine inimese kohta samal perioodil 40\%. Aastatel 1986-1989 oli fataalsete alkoholimürgistuste arv püsivalt väike, märgatavalt sagenesid need alles 1990. aastal (Baburin \& Gornoi \& Leinsalu \& Rahu 1997: 93). Alkoholimürgistuste arvu muutuste ja absoluutse alkoholi tarbimistrendide sarnased arengud lubavad väita, et müügipiirangute karmistamisega ei kaasnenud illegaalse alkoholi ja surrogaatide tarbimise tuntav suurenemine.

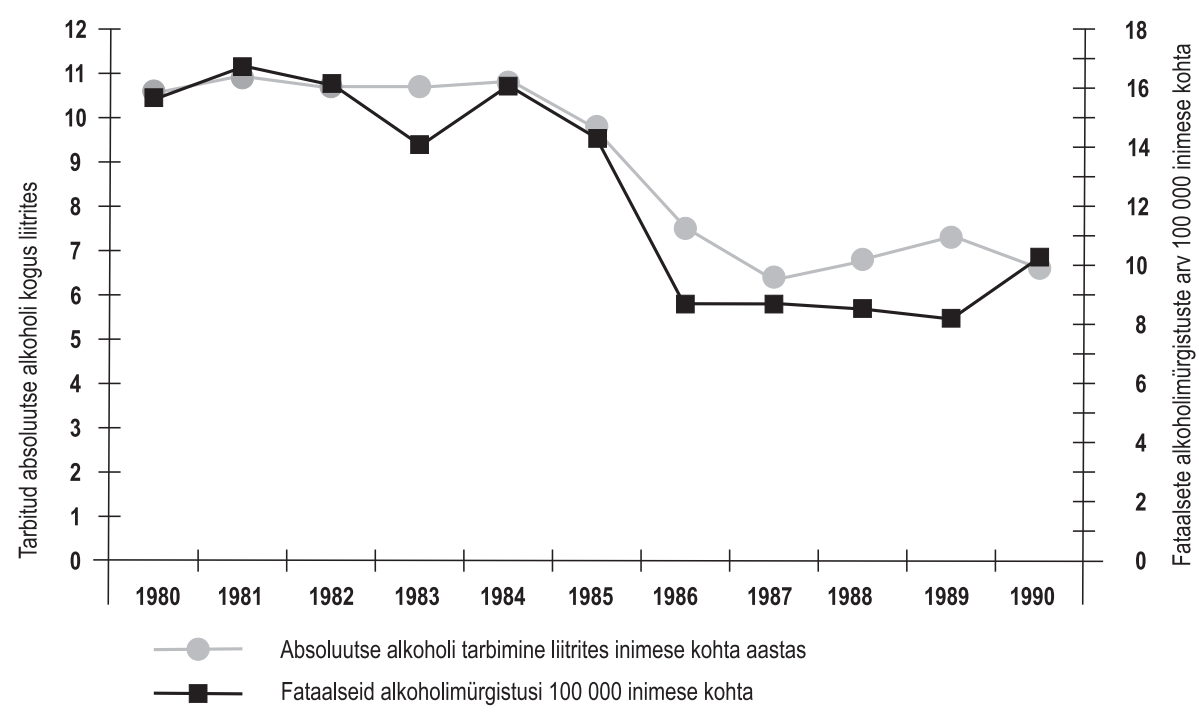

Joonis 3. Fataalsete alkoholimürgistuste arv ja absoluutse alkoholi tarbimine Eesti NSVs aastatel 1980-1990 (allikad ja arvutusalused: ERA, f R-1969, $n$ 4, s 809, 835, 863, 889, 911, 939, 964, 1014, 1060, 1132, 1179; Baburin \& Gornoi \& Leinsalu \& Rahu 1997). 
Elanikkonna alkoholitarbimist iseloomustab ligikaudselt ka alkoholipsühhooside esinemise sagedus. 10-13\%-l alkohoolikutest kujunevad kõige ulatuslikumad häired kesknärvisüsteemi tegevuses, mis avaldub psühhoosidena. Sellise tekkeskeemiga psühhoose nimetatakse alkoholipsühhoosideks. Et enamiku alkoholipsühhoosi liikidega kaasnevad elavad meelepetted ja silmatorkavalt kummaline käitumine, jõuab valdav osa haigestunuid peagi psühhiaatrite hoole alla ja seega fikseeritakse enamik alkoholipsühhoosi juhtumeid ametlikult (Saarma 1989: 201). Nii alkoholipsühhoosidesse haigestunud inimeste kui ka vastava diagnoosiga hospitaliseeritute hulk kahanes 1985. aastast märgatavalt. Haigestunud inimeste arv oli kõige suurem 1984. aastal, sealt edasi hakkas see kahanema ning 1980. aastate teiseks pooleks jäi kõnealuse diagnoosiga inimeste hulk märgatavalt väiksemaks kümnendi esimese poole vastavatest näitajatest (Liiv 2000: 301). Võrreldes 1984. aastaga kahanes alkoholipsühhooside hulk 100000 inimese kohta 1987. aastaks $57 \%$.

Kõrvutades eespool esitatud legaalse alkoholi müügil põhinevaid arvutusi alkoholi tarbimise kohta fataalsete alkoholimürgistuste ja esinenud alkoholipsühhooside arvuga, on näha näitajate märgatavat langust pärast 1985. aastat. Kaudsed alkoholitarbimist iseloomustavad näitajad ja legaalse alkoholi müüginumbrid annavad alkoholitarbimise üldistest trendidest pildi, millest võib järeldada illegaalse alkoholi ja surrogaatide pruukimise vähest levikut. Juhul, kui põrandaalune alkoholitootmine oleks olnud laiemalt levinud või hoogustunud ametlike müügipiirangute tulemusel, poleks legaalse alkoholi müügi järsk vähenemine ja muude alkoholitarbimist iseloomustavate näitajate langus omavahel sedavõrd tugevalt seotud.

Mitmed uurimused kinnitavad vigastussurmade ja enesetappude esinemise sageduse tihedat seost alkoholitarbimisega (Kaasik 2002: 95-107; Värnik 1997b; Värnik 1997c: 260-263; Värnik 1998: 13-19; Wasserman, Värnik, Eklund 1994: 306-313). Joobnu ettevaatamatu käitumine on ohtlik nii talle endale kui ka ümbritsevatele inimestele, põhjustades sageli traumasid, mis halvemal juhul võivad olla fataalsete tagajärgedega. Samuti on oluline osa suitsiididest tingitud alkoholi liigsest pruukimisest, mitmed autorid järeldavad ligikaudu 50\% meeste ja 27\% naiste suitsiidide seotust alkoholi kuritarvitamisega (Värnik 1997a).

Võrreldes 1980. aastate alkoholitarbimise näitajaid vigastussurmade arengutrendidega, ilmneb nende näitajate tugev seos. 1980. aastate esimesel poolel oli nii meeste kui ka naiste vigastussuremus ${ }^{1}$ märgatavalt kõrgem kümnendi teise poole vastavatest näitajatest. Oluline vigastussurmade vähenemine tekkis 1985. aastal, eriti tuntavalt vähenes näitaja meeste puhul (Baburin \& Gornoi \& Leinsalu \& Rahu 1997: 92). Seda ei põhjustanud ainult fataalsete alkoholimürgistuste vähenemine, sest suuremal või vähemal mää- 
ral kahanes kõigi vigastussurmade liikide esinemissagedus (Kaasik 2002: 98). Meeste vigastussuremus kahanes aastatel 1984-1986 ligikaudu 29\%, naiste vastav näitaja umbes 17\%. Aastatel 1986-1988 püsis vigastussuremus kümnendi madalaimal tasemel, 1989. aastal hakkas välistest teguritest põhjustatud surmade arv taas suurenema.

Suitsiidikõvera muutused sarnanevad üldistes joontes vigastussuremuse arvukuses aset leidnud arengutega. 1985. aastast alates hakkas suitsiidide arv elanikkonna hulgas märgatavalt vähenema, eriti tuntavalt vähenes see meeste hulgas. Kõige väiksem oli meeste enesetappude hulk 1988. aastal, 1984. aastaga võrreldes oli suitsiidikordaja vähenenud $31 \%$. Naiste suitsiidide hulk oli kõige väiksem 1987. aastal, mil suitsiidikordaja oli 1984. aasta näitajast $23 \%$ väiksem. Võib küll väita, et suitsiidide vähenemise tingis uus poliitiline ôhkkond, tekitades parema tuleviku lootusi. Muidugi ei saa ühiskonnas toimunud muudatuste mõju välistada, kuid arvestades suitsiidide arvu kasvu 1989. ja 1990. aastal, ei saa lootusrikkamate meeleolude võimalikku mõju üle tähtsustada.

\section{Kokkuvõte}

Juri Andropoviga lähedalt seotud Mihhail Gorbatšovi asumisega N Liidu etteotsa kaasnes mitmete J. Andropovi poliitiliste algatuste taaselustamine, sealhulgas tõusis päevakorda ka alkoholipoliitika karmistamine. Ilmselt poleks juhtkond alustatud kursilt taandunud, kuid majanduslikud põhjused sundisid kampaania peatama juba 1987. aastal - alkoholi tootmise oluline vähendamine kahandas tunduvalt alkoholi müügilt saadavaid tulusid ja riigikassa poleks kannatanud eksperimendi jätkamist.

Alkoholipoliitika karmistamise raames kitsendati joovastavate jookide kättesaadavust ning karmistati avalikkuses napsitamist puudutavaid reegleid, samuti sanktsioone alkoholiga seotud õigusrikkumiste eest. Veidi pehmematest võtetest saab nimetada avalikkusele suunatud karskuspropagandat ning püüdu avardada eneseteostuse ja vaba aja veetmise võimalusi. Unarusse ei jäetud ka juba alkohoolikute hulka kuuluvaid isikuid, laiendati narkoloogiliste raviasutuste võrku ja mitmekesistati raviteenuste vorme. Raske on öelda, millised kehtestatud meetodid osutusid efektiivseimateks. Selle kindlakstegemine polnud ka antud töö eesmärk.

Müüdud alkoholikoguste põhjal tehtud arvutustest järeldub, et uue alkoholipoliitika mõjul alkoholitarbimine Eestis kahanes - kui 1984. aastal tarvitati Eestis elaniku kohta keskmiselt 10,8 liitrit absoluutset alkoholi, siis 1986. aastaks vähenes see näitaja 7,5 ja 1987. aastal 6,4 liitrini. Muutus ka erinevate jookide osa tarbitud absoluutsest alkoholist. Mõningal määral vähenes kange alkoholi ja eriti piiritusveinide osa, tuntavalt kasvas õlle osa. 
Lisaks legaalse alkoholi kahanenud müüginumbritele kinnitab alkoholi tarbimise vähenemist ka fataalsete alkoholimürgistuste ja alkoholipsühhooside hulga tuntav vähenemine 1985. ja 1986. aasta jooksul. Samuti lubab fataalsete alkoholimürgistuste esinemise sageduses ja legaalse alkoholi müügitrendides toimunud muudatuste sarnasus järeldada, et legaalse alkoholi kättesaadavuse raskenedes ei kasvanud oluliselt illegaalse alkoholi ega surrogaatide tarbimine. Hoolimata range alkoholipoliitika lühiajalisest kestusest avaldus selle märgatav mõju ka nn välditavate surmajuhtumite arvule. Tuntavalt harvenesid vigastussurmad ja enesetapud. Vigastussuremus hakkas kahanema 1985. aastal ning jõudis 1987. aastaks kümnendi madalaimale tasemele. Koos alkoholipoliitika leebumisega 1987. aasta järel hakkas vigastussurmade arv taas kasvama. Üldjoontes toimus samasugune muutus ka suitsiidide esinemise sageduses: 1985. aastal algas kahanemine, madalseis saabus 1987. aastal ja sellele järgnes taas sagenemine.

Eelnevast järeldub, et aastate 1985-1987 alkoholipoliitikal oli mitmeid positiivseid tagajärgi. Samas ei võimalda eelnev analüüs anda lõplikku hinnangut toonaste alkoholipoliitika meetmete tõhususele. Esiteks rakendati meetmeid üsna lühiajaliselt - kampaania vältas vaid aastail 1985-1987. Pole välistatud, et alkoholi kättesaadavuse pikemaajalise piiramise korral võinuks potentsiaalsed puudujääki kompenseerivad mehhanismid, nagu illegaalse alkoholi müük ja valmistamine, pideva nõudluse püsides paremini tööle rakenduda. Teiseks ei võimalda kasutada olev andmestik analüüsida alkoholitarbimist eraldi vanuse- ja soorühmade kaupa, mistõttu ei saa teha tarbimisstruktuuri muutuste täpsemat analüüsi. Seega pole teada, milliste rahvastikurühmade alkoholitarbimine kõige enam muutus ning kas kõigi rahvastikurühmade alkoholitarbimise muutused olid ühesuunalised ehk kas joovastavate jookide tarbimine vähenes kõigis rühmades või esines kohati hoopis vastupidiseid arenguid.

\section{Kommentaar}

${ }^{1}$ Vigastussurmade all on mõeldud siinkohal välispõhjustest tingitud surmasid, mida rahvusvahelise haiguste klassifikatsioonis ICD-9 on tähistatud koodidega E800E999.

\section{Arhiiviallikad}

ERA, f R-1969, n 4 = Riigiarhiiv, fond R-1969 (Eesti Statistikaamet), nimistu 4 


\section{Kirjandus}

Abinõudest joomarlusest ja alkoholismist jagusaamiseks ning puskariajamise likvideerimiseks: NLKP keskkomitee 7. mai 1985. a otsus. 1985. Rahva Hääl, 17. mai.

Abinõudest joomarlusest ja alkoholismist jagusaamiseks ning puskariajamise likvideerimiseks: NSV Liidu ministrite nõukogu 7. mai 1985. a määrus nr 410. 1985. Rahva Hääl, 17. mai.

Abinõudest joomarlusest ja alkoholismist jagusaamiseks: NLKP keskkomitee 18. septembri [1985] otsus. 1986. Sütt, I. (koost). Karskus elu normiks: Seadusandlikud aktid. Tallinn: Eesti Raamat, lk 14-21.

Alkohoolseid jooke kuritarvitavate isikute sundravi ja tööga ümberkasvatamise kohta: Eesti NSV Ülemnõukogu Presiidiumi 24. aprilli 1965. a seadlus. Eesti NSV Ülemnõukogu ja Valitsuse Teataja 17, 1965, art 60.

Andrejeva, T. et al. (koost) \& Zamahhin, A. et al. (toim) 1988. Eesti NSV rahvamajandus 1987. aastal: Statistiline aastaraamat. Tallinn: Eesti Raamat.

Andrejeva, T. et al. (koost) \& Zamahhin, A. et al. (toim) 1989. Eesti NSV rahvamajandus 1988. aastal: Statistiline aastaraamat. Tallinn: Olion.

Baburin, Aleks \& Gornoi, Kaja \& Leinsalu, Mai \& Rahu, Mati (koost) 1997. Eesti suremusatlas = Atlas of mortality in Estonia . Tallinn: Eksperimentaalse ja Kliinilise Meditsiini Instituut.

Eesti NSV ministrite nõukogu 10. juuli 1972. aasta määruse nr. 334 punkti 2 alapunkti 2 muutmise kohta: Eesti NSV ministrite nõukogu 23. septembri 1976. a määrus nr 430. Eesti NSV Ülemnõukogu ja Valitsuse Teataja 40, 1976, art 389.

Ettevõtete, asutuste ja organisatsioonide ning nende struktuurüksuste joomarlusega võitlemise komisjonide põhimääruse kinnitamise kohta: Eesti NSV Ülemnõukogu Presiidiumi 10. jaanuari 1986. a seadlus. Eesti NSV Teataja 2, 1986, art 23.

Joomarluse ja alkoholismi vastase võitluse tugevdamise ning puskariajamise likvideerimise abinõude kohta: Eesti NSV Ülemnõukogu Presiidiumi 28. mai 1985. a seadlus. Eesti NSV Ülemnõukogu ja Valitsuse Teataja 17, 1985, art 292.

Joomarlusega võitlemise komisjonide põhimääruse kinnitamise kohta: Eesti NSV Ülemnõukogu Presiidiumi 30. märtsi 1973. a seadlus. Eesti NSV Ülemnõukogu ja Valitsuse Teataja 16, 1973, art 140.

Joomarlusega võitlemise komisjonide põhimääruse kinnitamise kohta: Eesti NSV Ülemnõukogu Presiidiumi 10. jaanuari 1986. a seadlus. Eesti NSV Ülemnõukogu ja Valitsuse Teataja 2, 1986, art 22.

Joomarlusest ja alkoholismist jagusaamise ning puskariajamise likvideerimise abinõude kohta: Eesti NSV ministrite nõukogu 28. mai 1985. a määrus nr 313. Eesti NSV Ülemnõukogu ja Valitsuse Teataja 26, 1985, art 449.

Joomarlusevastase võitluse tugevdamise kohta: NSV Liidu Ülemnõukogu Presiidiumi 16. mai 1985. a seadlus. NSV Liidu Ülemnõukogu Teataja 21, 1985, art 369. 
Joomise ja alkoholismi vastase võitluse tugevdamise abinõude kohta: Eesti NSV Ülemnõukogu Presiidiumi 30. juuni 1972. a seadlus. Eesti NSV Ülemnõukogu ja Valitsuse Teataja 28, 1972, art 284.

Joomise ja alkoholismi vastase võitluse tugevdamise abinõude kohta: Eesti NSV ministrite nõukogu 10. juuli 1972. a määrus nr 334. Eesti NSV Ülemnõukogu ja Valitsuse Teataja 32, 1972, art 344.

Joomise vastu peetava võitluse tõhustamisest ning korra loomisest kangete alkohoolsete jookide kaubastamisel. Eestimaa KP keskkomitee ja Eesti NSV ministrite nõukogu 26. jaanuari 1959. a määrus nr 23. Eesti NSV Teataja 9, 1959, art 46.

Kaasik, Taie 2002. Alkohol ja vigastussurmad Eestis. Viru, Atko-Meeme \& Volver, Anne (toim). Teadusvaade alkoholile. Tartu: Eesti Karskusliidu Karskusühendus AVE, lk 95-107.

Krooniliste alkohoolikute ja narkomaanide sundravi ja tööga ümberkasvatamise kohta: Eesti NSV Ülemnõukogu Presiidiumi 31. oktoobri 1975. a seadlus. Eesti NSV Ülemnõukogu ja Valitsuse Teataja 39, 1975, art 470.

Kuddo 1988 = Куддо, Арво. Социально-эконолические причины и последствия распространения пьянства и алкоголизла. Таллин: Академия наук ЭССР.

Liiv, Anti 1990a. Prevention of alcohol abuse in Estonia in 1984-1988. Актуальные 6опросы психиатрии и наркологии: Труди конференции, посвященной Х-летию Кохтла-ярвеской психонеброловической больницы. Кохтла-Ярве: [s.n.], lk 149-50.

Liiv, Anti 1990b. Alkoholismi sundravist IME tingimustes. Актуальные бопросы психиатрии и наркологии: Труди конференции, посвяченной Х-летию Кохтла-Ярвеской психоневроловической больнииы. Кохтла-Ярве: [s.n.], $\mathrm{lk}$ 51-52.

Liiv, Anti 1991a. Alcohol Problems in Estonia in 1980-s. Publication of the Center for Training and Development 9. Kuopio: CDT of the University of Kuopio, lk 31-38.

Liiv, Anti 1991b. Estonian Psychiatry in 1980-s. . Publication of the Center for Training and Development. 9 Kuopio: CDT of the University of Kuopio, lk 94-99.

Liiv, Anti 2000. Sõltuvushaigused sõltumatus Eestis. Rääts, Ebba (koost) \& Johandi, Evi \& Vaba, Mari (toim). Eesti uue aastatuhande lävel: Väikerahva võimalused ja valikud. Tallinn: Tea Kirjastus, lk 296-309.

Liiv, Anti 2004. Suuline teade artikli autorile.

McClellan, Woodford 1998. Russia: The Soviet Period and After. Upper Saddle River (New Jersey): Prentice Hall.

Muudatuste ja täienduste tegemise kohta Eesti NSV seadusandluses seoses NSV Liidu Ülemnõukogu Presiidiumi 1974. a. 25. aprilli seadlusega "Võitluse tugevdamise kohta narkomaaniaga": Eesti NSV Ülemnõukogu Presiidiumi 30. augusti 1974. a seadlus. Eesti NSV Ülemnõukogu ja Valitsuse Teataja 37, 1974, art 369.

Muudatuste ja täienduste tegemise kohta ENSV Ülemnõukogu Presiidiumi 24. aprilli 1965. a. seadluses "Alkohoolseid jooke kuritarvitavate isikute sundravi ja tööga ümberkasvatamise kohta": Eesti NSV Ülemnõukogu Presiidiumi 25. augusti 1967. a seadlus. Eesti NSV Ülemnõukogu ja Valitsuse Teataja 38, 1967, art 303. 
Muudatuste ja täienduste tegemise kohta mõnedes Eesti NSV seadusandlike aktides: Eesti NSV Ülemnõukogu Presiidiumi 18. novembri 1985. a seadlus. Eesti NSV Ülemnõukogu ja Valitsuse Teataja 37, 1985, art 579.

Saarma, Jüri 1989. Narkoloogia: Käsiraamat. Scripta medicorum. Tallinn: Valgus.

Suny, Ronald Grigor 1998. The Soviet Experiment: Russia, the USSR, and the Successor States. New York \& Oxford: Oxford University Press.

Zenkovitš 1999 = Зенькович, Николай А. Тайны уходящего века 3: Лжесвидетельства, фальсификаиии, колпролат. Досье. Москва: Олма-Пресс.

Täienduste ja muudatuste tegemise kohta Eesti NSV kriminaalkoodeksis: Eesti NSV Ülemnõukogu Presiidiumi 28. jaanuari 1983. a seadlus. Eesti NSV Teataja 3, 1983, art 24.

Värnik, Airi 1997a. Enesetapud Eestis 1965-1995 = Suicide in Estonia, 1965-1995. Tallinn: JMR.

Värnik, Airi 1997b. Suicide in the Baltic Countries and in the former Republics of the USSR. Stockholm: Karolinska Institute.

Värnik, Airi 1997c. Meeste ja naiste suitsiidid Eestis aastail 1970-1994. Eesti Arst 3, lk 260-263.

Värnik, Airi 2002. Perestroika-aegse range alkoholipoliitika tulemused. Viru, AtkoMeeme \& Volver, Anne (toim). Teadusvaade alkoholile. Tartu: Eesti Karskusliidu Karskusühendus AVE.

Wasserman, Danuta \& Värnik, Airi \& Eklund, Gunnar 1994. Male suicides and alcohol consumption in the former USSR. Acta Psychiatrica Scandinavica 89, lk 306-313.

Wasserman, Danuta \& Värnik, Airi \& Eklund, Gunnar 1998. Female suicides and alcohol consumption during perestroika in the former USSR. Acta Psychiatrica Scandinavica $98, \mathrm{lk} 26-33$.

Üleliidulise Vabatahtliku Karskusühingu põhikiri = Устав Всесоюзного добровольного обицества борьо̆ за трезбость: [Kinnitatud 25.09.1985]. 1985. Tallinn: Eesti Raamat.

\section{Summary}

\section{Gorbachev's temperance campaign and its consequences in Estonia}

Kelli Arusaar-Tamming

Key words: alcohol policy, alcohol consumption, healthcare, social politics, injury fatality

The issue of reducing the consumption of alcohol became a topical issue among the Soviet authorities in 1982, but as a result of the following frequent substitutions in the organs of power the planned measures could not be applied. In 1985, Mikhail 
Gorbachev, being appointed secretary general, once again raised the issue, and began to carry out a considerably stricter alcohol policy. The new and unprecedentedly strict alcohol strategy was being carried out according to the guidelines sent from Moscow in all the Union Republics, including Estonia.

The alcohol strategy implemented in 1985-1987 covered different fields and was not only about restrictions on the sale. Attention was also paid to preventive methods - propagating abstinence as well as offering new choices to spend free time. The availability of alcoholic drinks was aggravated by setting stricter limits on the sale, increasing the prices of alcoholic beverages and also by increasing the penalty for illegal sale and use of alcohol. Several changes were made to provide better availability of narcological aid. The new administration would not have withdrawn from the once started policy, but economical difficulties brought it to halt as early as in 1987. The significantly reduced production of alcohol lead to the slumping of profits from the sale and the treasury could no longer afford to continue the experiment.

The purpose of this paper was to give a thorough survey of the methods of the 1985-87 alcohol strategy and to look into the consequences of developing a stricter official alcohol strategy in Estonia, especially the effects on consumption habits. The descriptions of the official alcohol strategy are based on the decrees of the Communist Party of the Soviet Union, also the official documents issued by local authorities, legislative and executive bodies. To evaluate alcohol consumption, the author has basically relied on the statistics of the sale of alcohol. The source of the data is the departmental reports of the Central Statistical Office of the ESSR to the USSR Federal Statistical office on the sales of alcohol in Soviet Estonia. The data of the reports must be reliable as these were confidential documents intended only for official use.

It may be concluded from the estimations of the amount of the alcohol sold that as a result of the new alcohol strategy, alcohol consumption in Estonia decreased considerably: from 10.8 litres of absolute alcohol per capita in 1984 to 7.5 litres in 1986, and 6.4 litres in 1987. There was also a change in the different types of alcoholic drinks consumed. The consumption of strong alcohol, especially different types of wine, decreased to some extent, while the relative proportion of beer consumption increased. In addition to the decreased figures of legal alcohol sale the decrease in alcohol consumption is confirmed by the drastic fall in the rate of alcohol poisoning fatalities and cases of alcoholic psychosis in 1985 and 1986; during the period of 19851986 the rate of alcohol poisoning fatalities was reduced by half. The similarity of changes in the frequency of alcohol poisoning fatalities and tendencies in legal alcohol sales allows us to conclude that under the circumstances of restricted sale of legal alcohol the consumption of illegal alcohol and surrogates did not considerably increase. The temperance campaign and contingent fall in alcohol consumption was effective in decreasing the number of fatalities in injuries and suicides. 